\title{
Short Film and Video Producers and Film Policy Developments in Anglophone Sub-Saharan Africa
}

\author{
Patrick Edem Okon
}

Department of Mass Communication, Covenant University, Nigeria

Copyright (C) 2016 by authors, all rights reserved. Authors agree that this article remains permanently open access under the terms of the Creative Commons Attribution License 4.0 International License

\begin{abstract}
This paper examines the interventionist role of independent short film producers and alternative film foundations in film policy developments of Anglophone Sub-Saharan Africa. The work is broadly located within the framework of the debates about 'shapers' of film policy developments and covers only the last two decades (1990-2010). Empirical data are drawn from three countries: South Africa, Ghana, and Nigeria. The data are based on a study I conducted between 2011 and 2014. The study deploys mixed method approach (oral interviews, participant observation, documentary studies, and questionnaire) in a qualitative way, to enable data triangulation and comparative analysis. Jürgen Habermas and David Sholle's configurations of the public spheres concept are used to aid interpretation and analysis. The overall ambition is to critically articulate and interpret the sociopolitical dynamics of film policymaking, reconceptualize film policy along an 'ethical-political' framework to align with the vision of alternative cultural producers, as well as ascertain the degree and platform of participation of short filmmakers in the film policymaking processes. The paper argues in favour of greater academic and public recognition of the crucial role of low-budget film producers as policy activists.
\end{abstract}

Keywords Access, Participation, Reform, Film Policy, Independent Short Filmmakers, and Alternative Film Foundations

\section{Introduction}

Filmmaking of any kind, whether amateurish or professional, commercial or noncommercial, remains an incredibly popular pastime and an expression of a wide range of creativity and artistry. Also, any study of film and filmmaking, regardless of the specific research focus, should privilege among other things policy considerations. The importance of policy discourse to filmmaking cannot, therefore, be over emphasized; that is because, outside the personal and controlling artistry of the film director and the occasional requirements for division of labour, it is proactive film policy, in its diversified forms, that provides the inevitable mechanism for the effective organization of cinema industries and the very processes of filmmaking, distributions, and consumptions across nation-states. But more significant to that discourse is a critical consideration of how the structuring of the processes and the sociopolitical platforms of film policymaking across Africa encourages broader intellectual interventions and co-regulation, especially by those at the margins of society.

Over the years, the participation and the interventions of alternative cultural producers in national film policy development in Africa and elsewhere has remained an unregarded aspect in media policy debates. Mapping and documenting their importance as policy activists, at least from theoretical and empirical perspectives, is the core concern of this chapter. The work also attempts to respond to controversies within scholarship with regards to the marginal or non-marginal role of civil society groups in policy considerations [4]. The issues raised in this paper are not 'final', they are moderate contributions meant to trigger further discussions among academics and practitioners. The issues at stake may, therefore, be tied around the following questions: how can we reconceptualize film policy in a way that is sophisticated and acceptable to alternative film producers? What is the contributive role of short film producers in film policymaking? Is there democratic deficit in the framework for film policymaking in Angophone Sub-Saharan Africa?

\section{Framing the Key Theories}

In sync with the concerns of the field of Media and Society in relation to how expressive popular cultures enable the evolution and organization of human society, cultures, and democratic politics or promote inequality and the stunting of cultural development of economically and technologically disadvantaged communities is the concern of democratic-participatory communication theory. Though varied, this theory generally advocates multiplicity of media 
forms, small-scale media practices, the deinstitutionalization and deprofessionalization of media systems, interactive media organization, and the participation of audiences in information productions and circulations $[8,21]$. Democratic-participatory communication theory, in a nutshell, poses a 'democratization' challenge to the ideology, production, and regulatory requirements of media systems and industries.

Useful for articulating the core concerns of this theory is Jürgen Habermas' bourgeoisie public spheres concept; particularly its concern with issues bordering on 'access', 'participation', and the 'political economy' of media industries. This work draws on these theoretical benefits of the public spheres model of democratic-participatory communication theory to give direction to the discourse on the role of independent short filmmakers in contemporary film policy developments of Anglophone Sub-Saharan Africa.

The choice of this concept is essentially informed by the following factors: It can provide a broad theoretical framework for thinking through and conceptualizing the necessary links between alternative filmmaking and normative processes. The concept recognizes democratic frameworks as the necessary mechanisms for effective media normativity and the promotion of alternative mode of communication that favours the participation of citizens in the construction of social meanings within nation-states. It locates alternative filmmaking within the framework of media activism and the global movements to transform communications, so that communications and representations can be less constrained by bureaucracy or commercial interest and remain increasingly open to positive social values. A reinterpretation of the public spheres concept, in line with the policy vision of alternative media, will be effective for understanding the need to integrate the critical-rational with the affective concerns of citizenship, as well as practical productions of alternative meanings with practical strong policy interventions by low-budget cultural producers.

The Habermasian bourgeoisie public spheres, those imaginary arenas where ordinary citizens assemble to engage freely in critical-rational debates about official policy positions as well as form and express opinions through print media (newspaper and periodicals), problematizes the democratic deficit that was the hallmark of most democratic capitalist societies of Western Europe in the sixteenth through nineteenth centuries. This democratic deficit was constituted primarily through the deployment of top-bottom administrative strategy, one-way communication, and coercive political power by the ruling aristocrats in the organization of State affairs and in decision-making. The remote nature of noble political life and engagements and the increasing placement of emphasis on coercion as conditions for the legitimization of political organization, social life, and power of social control, in the view of Habermas, were some of the factors that eventually brought about disillusionment and apathy among ordinary citizens of
Western European nation-states, informing the evolution of the coffee houses, salons, and table societies as alternative spheres of deliberation and education.

However, it was the contradictions in the very mode of operation of these bourgeoisie public spheres, brought about by the existence of constellation of divergent interests that was not properly harmonized to strengthen broader access and participation, as well as the gradual placement of emphasize on the power of capital over and against continuing civic empowerment by the middle class business elites who controlled the means of information distribution within the public spheres, which eventually led to their final disintegrations and transformations in the early part of the twentieth century.

As noted by Marris and Thornham [17], the Habermasian concept of the public spheres was not merely an abstraction that lacked foundation in reality; but derived its specific meaning from a concrete historical situation of minimalism, coercion, monopolization, exploitation, and political exclusion. While the positive logic of the Habermasian public spheres "seeks to move social realities beyond the flawed realities of history to recover something of continuing importance to progressive and participatory democracy [3:4], some of the pitfalls inherent in his conception of the public spheres has over the years brought about a tradition of revisionist approaches that aim to make the concept more relevant to the needs of contemporary scholarship.

\section{Sholle's Alternative Policy Intervention Advocacy}

David Sholle's [25] revisionism draws on Negt and Kluge's [20] arguments concerning proletarian self-consciousness to establish a value relationship between proletarian public spheres, alternative media practices, and the need for the constitution of alternative movements to ensure strong media policy interventions in favour of citizenship. Sholle recognizes that the distinctive link between the activities of the alternatives and proletarian publics rests on what Negt and Kluge refer to as emancipatory communication (i.e. "the objective conditions under which the human being can become more of a subject and can build more autonomous and more comprehensive relationships to reality" - $[25: 23]$ and on the utopianism advanced by Enzensberger and Brecht, who both critiqued the one-way functioning of dominant media and see the potential of media technology, not in terms of mechanisms for the distribution of commerce, but as tools for public communication and education.

Sholle's core arguments are, firstly, that "alternative forms of media can serve as models for more expanded strategies for developing democratic modes of communication, but they cannot in themselves bring about the media utopia they sometimes espouse" [25: 34]. Secondly, alternative media groups will be able to transform public spheres activities if only they can think through a number of issues: the strategies 
they adopt in the production of meanings, the kind of people that engage with them in the design of contents and distribution networks, and their conception of audiences and access (audience as universalized, enclave or diverse; access as access to technology, audiences, and/or political impact?). Thirdly, the attainment of the transformative objectives of the alternatives further requires that alternative media practices move beyond the mere realm of the Habermasian critical-rational argument that are structured primarily on set of logical rules as well as the realm of practical economic production implied in Negt and Kluge's arguments, to the recognition of the value of affective experiences of citizenship to political engagements and the need to engage regularly in activism to affect official policy positions.

The value of Sholle's reinterpretation of the Habermasian bourgeoisie public spheres to this work rests on the following: the links he makes between public spheres and alternative media; his emphasis that the use of the concept in contemporary times should recognize, not only the value of candid and rational arguments, but more importantly the significance of affective historical experiences of citizenship; his strong advocacy that alternative media groups reorganize themselves and define their practices, not only in terms of concrete contents productions, but also in terms of strong interventions in proactive policymaking; and his recognition of the limitations inherent in small media interventionist capability, caused by the small-scale nature of the practice. In particular, his observations with regards to strong policy intervention and the integration of affective experiences of citizenship into media policy-making, fundamentally, align with the primary objectives of this paper.

\section{Who Are the Independent Short Film Producers?}

The field of independent film and video production is extensively heterogeneous, covering a wide range of experimentalists and even professionals. This reality has been recognized by a number of film scholars $[1 ; 9]$. Even the definition of 'independent small filmmaking' has been contested both in literature and public discourse by filmmakers themselves. The phrase has acquired a myriad of definitions depending on who uses it and for what purpose. The diversity in the understanding of independent film practice is itself evident even in the different phrases used within scholarship to describe it, such as 'reality cinema' [7], 'documentary filmmaking' [24], 'visionary filmmaking' [26], 'critical cinema' [16], 'radical film practice' [6], 'marginal film practice' [2], 'alternative cinema' [10], 'independent filmmaking' [9], 'avant-garde filmmaking' [27], 'underground film production' [23], etc.

The varieties within the alternative sector can, however, attain some level of congruence within the conceptual framework of 'national cinema', a common label for non-Hollywood cinemas and art films, which boundary is today also very complex [5]. For Murray Smith [27], the only thing that unites the variations is the status of the independent filmmaking as 'other' to orthodox narrative filmmaking. Indeed, the boundaries surrounding what may be counted today as an independent short filmmaking is becoming increasingly blurred, particularly as camera formats and digital technologies overlap.

Nonetheless, the concept is today more closely aligned with the more modest independent film projects undertaken by less well known filmmakers, working either singly or collectively. Short filmmaking, therefore, can be approached either as a genre or an aesthetical style; as financing model or a filmmaking philosophy. The category is generally characterized by the following: greater freedom of personal control over the production process; reasonable level of freedom from professional compromise; low-budgeting; diversification in financial sources; oriented to counter commercial filmmaking in its areas of dominance - narrative and classic realism; made not for theatrical markets or big screens but for niche markets and small screens; and functions to enable independent filmmakers double up on jobs [1].

Technically then and within the context of this chapter, independent short filmmakers are those who engage in small-scale artisanal and collective film production that address social and cultural issues, as well as in the political activities of activist film foundations, film societies, or coalitions concerned with the promotion and defense of the political interests of the independent small-scale sector. Generally, those within this category of filmmaking are drawn along two tendencies: the 'parallel' and 'reactive' tendencies [27]. As parallel otherness, individual avant-garde filmmakers who have had little interest in the commercial cinema intentionally forge a parallel aesthetics with the commercial film industry while at the same time staying bound up to the rhetoric of the alternative industry. And as reactive otherness, the avant-garde producers continually challenge and undermine both the norms of orthodox aesthetic practice and the established values and politics of mainstream filmmaking (rationalization, specialization, commodification, and reduction of film value to mere entertainment).

\section{The Ethical-political Approach to Film Policy}

Film policy is part and parcel of the broader media policy study. Film policy addresses a wide range of issues that include the structural, ethical, censorship, regulatory and economic principles employed to organize cinema systems and industries across national and transnational contexts. While different ideological, technological, economic, and cultural contexts often condition and shape its configuration and implementation across nation-states, the attainment of a unified definition of film policy is still problematic. The variations in the conception of film policy are determined, principally, by contexts and purposes of study. 
Yet, contemporary conception of film policy confers it with a multidisciplinary character, heterogeneity of policy themes, as well as the fact that film policy, however conceived, does usually make some reference to the notion of public interest. Though governments have generally been seen as the principal player in film policymaking, film policy actors and institutions have become increasingly diverse. Various parties, institutions, corporate bodies, interest groups, and practice categories now lobby to influence the final film policy outcomes across nation-states. In other words, the sociopolitical dynamics of film policymaking and policy implementations is rapidly changing. Driven by globalization, internet, and international co-production treaties, the process is becoming even more and more complex, offering challenges to policymaking processes that have traditionally handled separate industrial economies.

Stylianos Papathanassopoulos and Ralph Negrine [22] highlight three existing approaches that could be drawn upon to understand the sociopolitical dynamics of film policymaking: State-centric approach (left or right) whereby the state makes final policy decisions based on its scope and resources and without subjecting the outcomes to pressures from civil societies; Group-oriented approach which outcomes are based on the broadest possible collective actions and reconciliations of a wide range of vested interests within the polity; and State-society approach which entails the mobilization and co-opting of a limited range of compatible interests into the policymaking process to create a form of intermediation between state and society. This sociopolitical dynamics could also be validly applied to policymaking in relation to all other media sectors.

While film policy has been defined differently and the mechanisms of participation broadened in recent years to recognize the interrelationships among themes and actors, for the purpose of this work, I propose an 'ethical-political' conceptual approach. In making this proposal, I am conscious of two contradictory positions: on the one hand, Hallin-Mancini's [12] call for the framing of new and more sophisticated conceptual frameworks for the analysis of media policy other than that offered within the traditional normative theory; on the other hand, critical scholarship's objection against what it considers the invention of new repertoires of concepts or taxonomies and approval of an integrative approach to the existing stock of knowledge about policy study [22]. It is precisely the recognition of the need for a more sophisticated conceptual framework and integrative dimension to further strengthen existing co-regulatory frameworks or restore the often missing empathetic and moral contents to film policymaking that inform and justify the proposal of this new conceptual approach.

The ethical-political approach draws extensively from the benefits of the 'group-oriented' approach that is interest- and venue-based and only secondarily from the 'state-centric' and 'state-society' approaches. It recognizes the importance of 'affective' and 'critical-rational' contents to film policymaking, as well as the need for film policy unification to be achieved through the integration of 'alternative' and 'mainstream' policy concerns. While alternative policy visions are centrally tied around the questions of 'politicized interests', democratization of cinema systems, and 'emancipatory representation', the mainstream policy concerns are often conditioned by professionalized conventions and the deployment of the administrative technicality of governments' policy experts. The ethical-political approach if adopted, it is argued, will also ensure the integration of moral and empathetic contents with logical considerations into film policymaking processes.

\section{The Epistemological Framework}

The epistemological framework for the configuration of the ethical-political is drawn from David Hutchison's "sceptical liberalism" [14: 4]; that is, a right-based theoretical framework that questions the absolute agency of government to determine political and legal truths [21]. The ethical-political, therefore, makes an appeal for the continuing recognition of the importance of 'policy community' and 'policy networks' [13] as valuable social mechanisms for enabling accountability and new entrants into the policymaking arenas of governments. This approach presents a distinctive epistemological framework for understanding the kind of co-regulatory vision independent filmmakers would bring to bear on national and transnational regulatory and deregulatory processes in relation to film systems, industries, and institutions. In this regard and drawing insight from Albert Moran [18], I define film policy, not only in terms of normative principles, but as strategies (ethical, political, economic, legal and social) through which film systems, production processes, and industries are regulated and funded against the backdrop of the mundane and rational politics of bureaucratic and public life.

\section{The State of Short Filmmaking in the Sub-Sahara}

The empirical data on the diversity of independent short filmmaking across South Africa, Ghana, and Nigeria indicate that small-scale independent filmmakers have continued to emerge in Africa over the years, ready to make films that contribute in significant ways to the growth of the fabric of African filmmaking and desirous to have their "voices" heard in the public spheres of the African nation-states. Anglophone Sub-Saharan Africa is now a home to thriving communities of small-scale independent film and video producers. The African region is also hugely prolific even in the number of metaphors used to signify this experimental industrial category of filmmaking. Three categories of short filmmaking have been identified by respondents from across the three countries: those embarked upon by independent filmmakers for some community development agencies for promotional and advocacy purposes; those undertaken by 
amateur producers to record social functions such as weddings, birthdays, and funerals for the purpose of minimal profits from their clients; and those productions undertaken by educational institutions where students are assigned or voluntarily undertake to produce short films and videos as part of their training requirements. While the first two categories are generally of an informal economic structure, the third is of a formal or semi-formal structure.

\section{a) Ghana}

Respondents from Ghana admit that the independent short film sector is still growing in the country. But generally short video productions undertaken purely as community initiatives are now a rarity in Ghana. Only private individuals and institutions occasionally undertake documentary and fictional short filmmaking to sensitize and promote health, environmental, human rights and justice awareness concerns. For example, The Witches of Gambaga, a documentary film produced by Yaba Baidoe in 2010 chronicles the dehumanizing story of "the witches' camp" in Gambaga, a town in the Northern region of Ghana. This film is the outcome of a collaborative initiative between a number of female activists and the "community of witches" determined to end abusive practices and improve women's lives in Ghana. There is also a film on HIV/AIDS that was produced in 1993 for the National Film and Television Institute (NAFTI) by the Kumayo Boys. This film was aired for weeks by the national broadcaster.

However, what is conceived today as independent short filmmaking is substantially driven by commercialism and the cartel-like business approach of 'Gallywood'. Gallywood is a private commercial company under ACUFE media organization that functions to showcase Ghanaian artistic talents as well as offer land spaces for private producers to develop their trade. The cartel-like phenomenon began in Ghana in the 80 s with the advent of small video cameras and the deregulation of the media environment in the early-1990s. Before then film productions were done largely through the use of celluloid technologies and techniques. And only government acting through the Ghana Film Industry Corporation (GFIC), the big-time professionals, and commercial institutions could afford to use them. But since after the national film industry was practically sold out in 1996 to Channel 3, a Malaysian private television station, as part of government divestiture exercise, private citizens have increasingly gained access to small video technologies to make short non-fictional and feature-length films that help to advance educational, cultural, and linguistic values.

Vincentia Akwetey, the Dean of Studies at NAFTI, is of the view, firstly, that the entire production and circulation processes for short films in Ghana still requires a lot of streamlining through a comprehensive and enforceable national film policy, which formal approval is still pending before the Ghanaian Parliament. Secondly, it is only corporate bodies, development agencies, television stations, interested private producers, and educational institutions that now provide the needed funds to support documentary film and video productions in the country. Thirdly, the rate of locally-made independent short films stands as follows: Between 1970s and 2003 about 22 small films were made in a year. The statistics slummed after 2003. By 2009 there were about 69 short films produced locally. And in the first quarter of 2010 about 160 short films were produced. The statistics for 2011 and 2012 were not available from the Ministry of Information at the time of my oral conversation with Akwetey.

\section{b) South Africa}

The kind of robustness and diversity in short filmmaking recorded in Ghana is even more pronounced in South Africa. Marc Schwinges, the Vice Chair of the South African Screen Federation (SASFED), in an oral conversation, indicates that about 1000 independent short films were produced in South Africa between 1990 and 2010. Among them were Nikiwe (Ingrid Gavshon, 2004) and Considerably Killing Me (Willam Grobler, 2005). Both films focused on the impacts of HIV/AIDs in South Africa. Others were Proteus (John Greyson, 2003), a film that gives substantial consideration to the issue of gay/lesbian rights, and Meisie (Darrell Roodt, 2007), an Afrikaans multi-award winning film that addresses the poverty and concerns of homeless people at the margin of South African society. Generally, though the themes, genres, and aesthetics of short videos and films vary greatly in contemporary South Africa, the kind of films that are being done in the most recent years tend to focus more on global issues. Schwinges observes that "a lot of times these films are no longer dealing with the specifics of the South African politics. They might be dealing with the cultures of South Africa; but not the politics to a large degree".

Viewing the development of documentaries in contemporary South Africa at the Third Film Indaba (Nov., 2009), Clarence Hamilton, the Head of Production and Development of the National Film and Video Foundation (NFVF), notes that, excluding television docudramas, between 1994 and 2008, 615 documentaries were produced at average of 41 productions per annum. "White" filmmakers produced $68 \%$ and "Blacks" $32 \%$ of documentaries. Male directors constituted $62 \%$ compared to $38 \%$ female directors. A conversion of this statistics into a frequency scale will show that, out of the 41 productions per annum, about 13 and 28 documentaries were made by White and Black directors; and 25 and 16 made by Male and Female directors, respectively (See the frequency table below). Hamilton further notes, firstly, that "the gap between gender and race of distribution of directors has been narrowing since 2004 as compared to the previous years". Secondly, about 494 documentary films were distributed through unknown channels; while about 121 were distributed through cinema and commercial television channels in South Africa. Nonetheless, between 2009 and 2015 these statistics would have changed considerably.

Evidently, South African short filmmaking, which early histories go as far back as the great documentary film tradition of the 1896, the few liberal texts that accompanied 
the Anglo-Boer War, the moral and political interrogative cultural productions of the 1950s undertaken by such pioneering directors like Jans Rauteubach and Van Rensburg, and the most recent progressive audio-visual activism of the 1980 s, has presently gained a wider international recognition. In other words, things are now better in the independent filmmaking sector in South Africa, precisely because of the lower budget quality of production; the near reasonable balancing in the gender and race distribution of production; the increasing awareness of the value of short films in addressing global issues and portraying socio-cultural and economic realities of South Africa, as well as in preserving popular memory and histories outside those provided in official South African records. Some of the factors that have contributed towards the recent astronomical growth in independent short filmmaking in the country include the following: the diversity of film festivals and short film competitions that encourage and showcase young talents, such as the Weekly Mail Film Festival organized in the 1980s; the M-Net's New Directions of the 1990s; the NFVF's annual award short film competition; the African Dreaming, a pan-African short film initiative; and other provincial production and distribution initiatives [2].

\section{c) Nigeria}

The kind of progress in short film and videomaking recognized in relation South Africa, regardless of the enduring challenges, does not exist in Nigeria. The Nigerian local film industry is, however, witnessing astronomical growth in independent feature-length production under the general name of 'Nollywood'. This sector is developed and funded principally by the independent marketers which head offices are spread across a number of national regions. Because of the dominance of the national cinema industry by the private marketers, respondents admit that, among ordinary Nigerians, there is now an existing confusion between independent short movies that draw on feature and non-feature genres to address social empowerment, health, justice, and human rights issues and what is popularly known today as 'Nollywood' feature-length films.

Onwurah Ifyeanyi, the Chairman of the Actors Guild of Nigeria (Abuja Chapter), in a face-to-face interaction, attributes the existing ambiguity to the fact that both cinema categories are now equally drawn into social activism. He admits, however, that there is still a vigorous culture of community short videos and films in the country. He singled out Inalé (Jeta Amata, 2010) as a good feature short film made recently in Nigeria. This film is a folklore and musical epic produced by Keke Bongos. It deals with the problem of human love and dignity within the context of royalty, slave-trade, and family oppression.

Outside the feature short film category, there are also the "crusading community videos" that highlight the underdevelopment problems of the oil-rich Niger Delta and the stark disparity in wealth distribution among the people of the geopolitical region. Also in existence are the documentary films which productions are often promoted and sponsored by the Nigerian government through the activities of the Nigerian Film Corporation (NFC). These documentaries, in varying ways, highlight the historical and socio-cultural experiences of Nigerians. For example, there are the "historical documentary videos" that tell the stories of the struggles for independence and the negative impacts of the Nigerian civil war of 1964-1972. There are also the short films and documentary videos produced by NGOs, cultural organizations, and educational institutions for onward transmissions through any friendly mainstream television stations and that have the capability of targeting wider audiences in Nigeria and beyond.

The comments of Obiora Chukwumba, the Special Assistant to the Director General of the Nigerian Film and Video Censors Board (NFVCB) dwell extensively on what the NFVCB is currently doing to encourage short film and community video productions in Nigeria. NFVCB is providing effective platforms for "mentoring and for some form of reward" to broaden the spaces for short film productions. One of such platforms is the "Homevida" (also known as the Nigeria's Home Video Integrity Film Award) that NFVCB is currently organizing with the Public and Private Development Centre (PPDC), a private NGO-managed company. While the principal movers of this award platform are the PPDC and the NFVCB, other government agencies, such as the Bureau for Public Procurement (BPP), the Code of Conduct Bureau (CCB), the United Nations Office on Drugs and Crimes (UNODAC), and the Economic and Financial Crimes Commission (EFCC) have now entered into the promotion of the scheme. Other governmental institutions that have shown interests in the award platform include the Federal Ministry of Health and the Federal Ministry of Culture.

The "award scheme" process is not simply about commercial benefits. It is principally about the need for a growing development of professional interest among young people, an escalation in independent short filmmaking to counter the hegemony of 'Nollywood' films, as well as a profound development of filmic messages geared towards behavioural changes. Chukwumba explains that the criteria for the evaluations of "award prizes" is rooted in the way each film correctly mainstreams the core values, social issues and messages that the partnering agencies of government are concerned about and the way each film successfully engages the public in discussions on a chosen value area for the purpose of behaviour change. He admits that there are so far five categories of award values: family-friendly, due process, public conduct, anti-trafficking in persons, and faith prize which has to do with religious values used in the service of the wider society.

On a critical note, generally short films and documentaries made in South Africa, Ghana and Nigeria for the purpose of activism are important because of their ethnographic styles and contents, as well as their engagements with the publics to promote issues relating to culture, identities, human rights, and education. Yet, a good number of short film producers still place emphasis on commerce and entertainment as their 
core practice values (See Figure 1 and Table 1 below):

Table 1. Comparative analysis of the state of short filmmaking

\begin{tabular}{|c|c|c|c|}
\hline Country & $\begin{array}{c}\text { Short videos as } \\
\text { community } \\
\text { initiatives }\end{array}$ & $\begin{array}{c}\text { Short videos as } \\
\text { private } \\
\text { commercial } \\
\text { initiatives }\end{array}$ & $\begin{array}{c}\text { Short videos as } \\
\text { voluntary/assig } \\
\text { ned school } \\
\text { projects }\end{array}$ \\
\hline Ghana & Rare & Thriving highly & Thriving \\
\hline $\begin{array}{c}\text { South } \\
\text { Africa }\end{array}$ & Thriving & Thriving highly & Thriving highly \\
\hline Nigeria & Thriving & Thriving highly & Thriving \\
\hline
\end{tabular}

Also, the Nigerian "award scheme" arrangement in particular, though apparently beneficiary to the Nigerian public, is still constrained by its specific focus on patronage drawn only from government agencies. There is need for increasing diversification, in terms of value areas, endowment institutions, and the engagement of participants from the private sector, so as to strengthen the reward-base of the scheme, heighten the production capacity of young producers, and re-orient the management of the entire cinema industry in the country.

\section{Key Policy Concerns of Low-Budget Producers}

Data reveal areas of policy concerns that are common across the three countries, as well as those that are unique to each legislative country. The shared film policy areas, though differently articulated by respondents, include copyright law reforms, funding support, strengthening co-regulatory partnerships, exhibition and distribution of films, the entry of young talents into the national industrial markets, and audience development and demography. But only three are considered below:

- Copyright law reforms - SASFED is concerned particularly with Section 21 of the South African Copyright Act (No. 98) of 1978 that came into effect in January 1, 1979, as well as how the national broadcasters misinterpret and apply it to deny independent producers the right to benefit from their creativity. Section 21 of the Act addresses the question of "ownership of copyright" of commissioned cinematographic film, if such work is commissioned either under an agreement for money payment or under a contract of service or apprenticeship. The national broadcasters, led by SABC, believe that the right of ownership of a commissioned cinematographic work (and even the leftover materials after editing) belongs "by default" to the commissioner of the work, rather than to the creator of the work. The implication of this is enormous. In particular, it means that the entire independent industry has become only an extension of the national broadcasters. In this regard, independent producers can only function under the guidelines provided by national broadcasters and under their mercy. While government recognizes that there are problems in the broadcasting sector in relation to the interpretation and application of a section of the national copyright law, Schwinges is of the view that government has never taken a decision to address the abuses encouraged by SABC and to protect the independent cinema sector. Shwinges admits that since the problem with the copyright policy is very much tied with the issue of self-regulation "for better employment conditions", SASFED is currently lobbying and pressurizing DTI to ensure the desired changes take place.

From Nigeria, the concern is with how the Copyright Act of 1982 (amended in 1999 and incorporated into the Copyright Act Cap 28 Laws of the Federation of Nigeria 2004) is being managed for effectiveness. Respondents streamline the areas of problems to include the challenges surrounding the creation of awareness with regards to the provisions of the copyright laws, the level of campaigning against copyright piracy, and the minimal exploration of partnerships with the media to enhance copyright awareness and curtailment of abuses of creative rights. In order to improve interventions in copyright administration, respondents recognize the need for improved partnership of the Nigerian Copyright Commission with the media sectors to enable the education of citizens; the need for the regulatory partners to readily provide data on copyright abuses on request by other stakeholders; the need for improved monitoring of the film, music, software, and book industries to ensure compliance; and the need for the immediate publication of findings with regards to alleged copyright infringements in the country.

Respondents from Ghana are concerned about the inefficient control of the entire audio-visual industry to manage film and video piracy, caused by the informal way the industry is currently organized. Even the political institutions expected to monitor and regulate on copyright abuses do not even have legal mandate to operate, which makes it difficult for people to listen to and follow their guidelines. In addition, most private producers still find it very difficult to get redress from the law courts once their creative rights have been infringed. Respondents admit that it is this kind of problem that has partly informed the campaigns for industrial legislations and a revised Copyright Act that could enable people demand for and obtain their rights or work within the legal parameters required by law. The most current copyright law of Ghana is The Copyright Act (No. 690) of 2005. The law was enacted and issued on May 17, 2005 to offer protection to a variety of creative works and to replace the previous Copyright Act (No. 110) of 1985.

- Funding support - Concern with funding was addressed from different perspectives, namely, the need for the diversification of funding sources caused by low government's funding arrangements and private sector 
funding initiatives; the difficulty in accessing funds from government establishments and financial institutions; how the available governments' grants for training, production, and employment promotion purposes could be fairly disbursed to benefit all stakeholders within each national industry; the need to bring discipline into the restrictive financial activities of the private marketers; as well as the need to improve on official funding to encourage quality productions, development of human resources, organization of film festivals, and national reward schemes.

Lindi Ndebele, the CEO of the Department of Arts and Culture (DAC) of South Africa, at the Third Film Indaba (2009), for example, admits that there is poor investment in films from the private sector in South Africa. She submits that the funding arrangements for the South African film industry comprises only government funding that comes mostly through DAC and the Department of Trade and Industry (DTI). This development, she explains, is due to the fact that South African films are generally considered to make relatively small income at the box office. Ndebele advocates for diversification of funding sources and investments to improve the sector.

Offering a contrary position, Schwinges of SASFED, while acknowledging the need for diversification, maintains that much of the finances invested in short films in South Africa come largely from private funding and from foreign philanthropic organizations that finance film productions that focus on human right issues. He admits that government provides only limited funding under five categories: SABC's commissioning of productions; sponsorship of experimental productions by those film schools partially-sponsored by government; NFVF's industrial development sponsorship; the loan or equity grants from Industry Development Corporation (IDC) for small business institutions; and the "co-production rebate" of DTI, first lunched in 2004.

The rebate arrangement is an outcome of the co-production treaties signed between South Africa and such other countries as the United Kingdom, Italy, Germany, Canada, India, Sweden, Algeria, etc., The rebate allows a $35 \%$ refund of the total amount spent within South Africa to any foreign company whose production initiative is recognized by its home country and South Africa as part of their co-production treaty agreement. This is in addition to the 'tax-free' and 'Vat-free' nature of co-production initiative. Shwinges observes that even much of government funding through DTI rebates system is aimed to benefit mostly foreign production partners. Local short film producers and the independent television sector are strategically excluded from benefiting from it. Independent film producers can, however, benefit (with minimal procedural stress) from the funding programmes offered by government through DAC and NFVF in terms of supports for scriptwriting, extensive or short-term apprenticeship for young entrants and for postproduction marketing.

Comparative data suggests that it is South Africa that currently offers the best funding opportunities for independent filmmakers. Nigeria and Ghana still have a lot to do in this regard. Arguably, lack of funding could be seen as partly responsible even for such tendencies as the fragmentation of films and videos contents into parts (Part 1, Part $2 \&$ Part 3) by independent producers and the reproduction of film sound-tracks into music videos for the purpose of additional profits. The availability of official funding, outside those drawn from private pockets and philanthropic organizations, has the capacity to affect the kind of infrastructures, talents, and quality productions available to national film industries. And lack of funding or diversification in funding sources can seriously impede progress in these and other directions.

- Strengthening co-regulatory partnerships - The NFVF 2010 "Draft Report on the Third Film Indaba" acknowledges and praises the current working partnerships exiting among relevant government departments, industry organizations, and independent producers in South Africa. The document further recognizes the need to strengthen partnerships between industry organizations, independent audio-visual producers, and political administrators at the provincial level in order to strengthen the entire South African cinema industry. Respondents, however, remain generally critical of the 'closed' relationship currently existing between ICASA and the independent audio-visual sector, which tends to dampen morale and minimize the capability of private producers to intervene directly in policy debates. Shwinges of SASFED admits that this is one of the primary factors responsible for low direct participation of short film producers in film policy decisions in South Africa.

Respondents from Ghana are concerned with the working partnership between the Ghana Academy of Film and Television (GAFTA) and the Federation of Independent Film Producers' Association of Ghana (FIPAG). Because of non-existence of legislative backing for the activities of the two bodies, they tend to work independently (and sometimes against each other), advancing divergent practice ideas to inform policy and film productions. While GAFTA favours policies that strengthen educational and cultural development as well as the promotion of nationalism, FIPAG places greater emphasis on policy initiatives that recognize its political and commercial interests. Awindor of GAFTA is of the view that effective organization of the film sector to ensure broader participation and progress will require stronger collaboration among all stakeholders.

From Nigeria, Chukwumba of NFVCB notes that film policy in Nigeria fall under the "Concurrent List" of the 
Constitution. By that provision, individual state can legislate on film and video matters alongside Federal government. State laws apply only within the state itself and are enforced only by state agencies. And where there is a conflict of law, the Federal law supersedes and the state law is declared null and void by a competent law court. But to avoid unnecessary conflicts in policies that regulates the film industry as a whole, as well as to reflect the multi-ethnic sensitivity of the country, NFVCB has had to adopt a "Shared-Responsibility System" (SRS) that allows for strong co-regulatory partnership, whereby representatives of states' regulatory agencies are brought into NFVCB to form a common platform for evaluating, classifying, and censoring film contents before their entry into the local markets. The SRS enables NFVCB get the understanding of all stakeholders in film regulation in Nigeria, to best manage the "Concurrent List" provision and avoid conflicts of interests, as well as prevent film producers from having to go through multiple censorship systems wherever their films are being distributed in the country.

Chukwumba admits that any attempt at unilateral regulation will yield only serious negative outcomes as was the case in Kano State in mid-1999, when the state government brought in Islamic policemen (or "Isbolla") to administer censorship on film contents produced and circulated within the state. The negative outcomes were enormous: films produced and/or distributed within the state were interpreted purely from Islamic perspective; attempts were made to redefine creative contents and to set legislative parameters on who has the right to create contents; most producers and actors who were not of the Islamic block deserted the state; and series of litigations arose from among industrial stakeholders, which "made a complete mess of the state government and its film policy direction". Astonishingly, the law could not even work to stop contents produced outside the state from getting into the state, precisely because of the limited logistics and power of monitoring and enforcement Kano state Islamic police had, as well as the power of digital media and mobile phones in aiding contents distributions. That era of folly, Chukwumba observes, came to an end only after May 2011 when a new government came into power in the state. He submits that any attempt at unilateral imposition of censorship in Nigeria without wider consultations will generate contention. It will amount to a serious breach of the law of free expression as guaranteed in the Federal Constitution.

\section{Campaigning for Film Policy Changes}

In considering empirical data on the question of campaigns by independent short filmmakers in South Africa,
Nigeria and Ghana for film policy changes, emphases was placed on such issues as the platforms and nature of campaigns, the type of horizontal and vertical linkages available to assist campaigns, as well as achievements and challenges. But because of limitation in the writing space, this section looks only at the platforms and nature of campaigns, as well as achievements and challenges.

\section{Platforms and Nature of Campaigns}

Respondents from the three countries agree that the platforms of advocacy for film policy reforms by independent short film producers stretches across a number of areas: documentary productions geared towards activism, street actions, partnerships with television houses and industry organizations, government ministries, conferences, workshops, and other sociopolitical forums.

\section{a) South Africa}

SASFED, a federation of independent industry organizations for audio-visuals in South Africa, was borne on January 3, 2007 out of government's request through DAC to have the independent audio-visual industry speak with one voice. One of the sociopolitical conditions for the establishment of SASFED was the recognition by South African government that there were existing problems in the audio-visual industry controlled by the national broadcaster $(\mathrm{SABC})$ and a few private commercial media institutions that needed to be addressed. Government did not want to speak with producers' organization, actors' associations and writers' guilds separately, with each presenting a different point of view. Government wanted to speak with the independent cultural production sector as a whole. SASFED was formed to provide an institutional platform for unified expressions by all stakeholders and to enable meaningful dialogue with government in matters pertaining to audio-visual policy initiatives.

Working in partnership with a host of other industry organizations and government departments, SASFED is currently providing the necessary industrial platform for campaigns and policy interventions for the entire independent audio-visual industry in South Africa. The institution, however, does not represent the interests of individual film and television producers. Rather it looks after the collective interests of its membership as a whole. Individual independent producers, working under specific associations, can lobby for changes in matters affecting their private interests either directly or through their specific industry organizations.

SASFED's activist services, however, rest completely on volunteerism. Both the Executive Council and the General Council of the federation are formed around volunteers drawn from its member organizations. While the General Council is the supreme governing and decision-making body, the Executive Council with ten members elected at the General Council's AGM is responsible for the day-to-day running of the federation. Thus, SASFED, guided by its two Councils, now remains the main advocacy and pressure body 
on audio-visual policy reforms as it affects the independent film sector as a whole.

In its struggles for film policy reforms, SASFED interfaces with national broadcasters and with government through a number of channels. The organization publishes a newsletter (known as "SASFED Newsletter") to promote its advocacy activities and the campaigning activities of its member organizations. The newsletter is distributed quarterly among SASFED friends and allies and to the public particularly through its official website. SASFED embarks on street actions and also uses documentary filmmaking as some of their tools for activism. Such public actions are always, of course, a collective activity of member organizations.

The organization also maintains direct interface with the relevant government departments on various issues. On the issue of changes to Section 21 of the Copyright Act, for example, SASFED deals with the Department of Trade and Industry (DTI) that has the ultimate responsibility to effect changes in the Copyright Act. SASFED also talks with government through the NFVF which has direct links with three governmental ministries, namely, the Department of Arts and Culture (DAC), the Department of Communications (DC), and the Department of Trade and Industry (DTI). This is in addition to the submissions SASFED makes directly to the three ministries without having to go through NFVF. Thus, SASFED dialogues with government both on the ministerial and the industrial levels. And to further strengthen its dealing with government on the industrial level through NFVF, SASFED signed a Term of Engagement (TOE) with NFVF in February 2011. The TOE agreement formalizes the relationship between NFVF (as government industrial agency) and SASFED (as the representative of the independent industrial sector).

Shwinges, the Vice Chair of SASFED, in a face-to-face conversation, notes that the level of direct participation of short film producers in film policy reform initiatives, outside the inputs made for them at industry organizational level, is very low. He explains that part of the reasons for their minimal direct contribution is that most of them are busy with making money to sustain their businesses. For him, this situation is further compounded by the awareness of private producers that "ICASA, the independent broadcast regulator, is incredibly impossible to deal with". For him, it is only at the industry organizational level that independent small film producers can have any chance of directly impacting on audio-visual policies in South Africa. He maintains that SASFED functions to provide for them that industrial platform.

\section{b) Ghana}

If campaigns for film policy reforms in South Africa remains one of the core mandates of SASFED, spearheading similar reform pressure in Ghana is GAFTA. GAFTA is an association of cinematographers established also on the basis of voluntary membership. GAFTA was formed by academics in partnership with some 'old' generation filmmakers in Ghana. It was established to provide an institutional platform for a central co-ordination of the independent audio-visual industry organizations. It is not the statutory regulator of the cinema industry. Though it currently lacks a national statutory mandate for its activities, the association is constituted to play a role similar to that of SASFED.

Jim Awindor, the former organizing secretary of GAFTA, notes that GAFTA functions more like an academy and as "an umbrella platform where all the other stakeholders can belong to so that we can have formidable resources to take care of the intellectual, social, political, and narrative structural needs of big-time and short-term filmmakers, as well as serve as a pressure body for the entire national audio-visual industry in Ghana". He explains that GAFTA does not deal with production matters. The production sector is directly under the management of FIPAG. GAFTA deals strictly with political as well as issues relating to narrative structures to provide guidelines to affect policy and production. This it does by pulling together all stakeholders in the audio-visual industry to belong under its network and to offer unified and formidable views on audio-visual policy matters.

For Awindor, there are four primary issues of advocacy that GAFTA is currently concerned with: The first is the lack of a comprehensive film policy system for the entire film industry in Ghana. Ongoing interventions on this issue, Awindor admits, depend on the political position of each successive government and on how that government satisfies (or fails to satisfy) the promises it gives to the citizens with regards to the National Film Bill. Awindor submits that there is generally lack of political will on the part of each government to get things better organized to bring back professionalism into the Ghanaian cinema sector as a whole.

The second is the provision of official supports for the independent short film sector. So far, government has offered little to the industry in terms of funding or technical support for the organization of film festivals. Most film festivals (e.g. FOFA) are organized by private organizations, such as Silver Bird Cinema. The only government support available to the industry, Awindor notes, is the "Ghana Youth and Employment Training" policy whereby government gives money to Gallywood to create avenues for the training and employment of young people in production. He admits that GAFTA currently works with a host of other stakeholders to ensure that things are better done to give a wide range of support to improve the independent cinema sector.

And the third is the current difficult relationship between GAFTA and FIPAG. FIPAG is a highly formidable association of marketers. Getting them to register and work with GAFTA is very challenging. The difficulty stems from a number of factors: Firstly, GAFTA lacks a "total recognition" from government that could enable it work effectively with FIPAG. Though GAFTA is registered with the Registrar General of Ghana as required by the company registration law and is affiliated with the Federation of 
African Filmmakers (the organizers of FESPACO), because it lacks a legislative backing, it is difficult for it to secure an enduring working partnership from FIPAG to reshape the cinema industry in Ghana. Secondly, there is an enduring animosity between some top members of GAFTA and FIPAG which keeps derailing the move towards collaborative partnership. FIPAG members still feel insulted by the statements made in the past by some prominent members of GAFTA who regarded them as cobblers, carpenters, shoemakers and people with low professional background who have infiltrated the filmmaking industry purely for personal gains. As a result, FIPAG remains highly suspicious of the practice intention of GAFTA which membership is made up of academics, veteran filmmakers, and renowned media activists. And because FIPAG members are mostly people working with "Gallywood" and other marketing associations, they still think they will not find a welcoming place in GAFTA.

The GAFTA-FIPAG drift and how this affects collaborative campaigns was further corroborated by Kwame Usuh, a Production Manager in Film Africa and TV Africa. As a result of the drift, Usuh admits, the film regulatory environment in Ghana is replete with regulatory illegality as different associations lay claim to being the rightful regulator of the cinema industry. He admits that if government is going to take the views of independent cultural producers seriously, such a representative and pressure group as GAFTA is needed. He argues that the situation currently calls for collaborative campaigns to ensure that GAFTA's attempt to gain monopoly of the industry is given legislative backing to ensure people's fidelity to its policy proposals.

With regards to role of short film producers in the formation of the National Film Bill and in the campaigns for its passage, Awindor and Ramatu Dadzie, the Head of Designs Department of NAFTI are in agreement that most of the short film producers who operate under FIPAG "don't care; in fact, they don't even know what the Film Bill is". And because their goal is commercial benefits, many of them don't bother about regulatory issues. The pressures for film policy reforms in Ghana come mostly from the academia, GAFTA, professional journalists, and/or media activist organizations. Independent short film producers make little direct inputs.

Respondents from Ghana are generally of the view that the problem with minimal participation of short filmmakers in regulatory reforms is not lack of 'forums' (conferences, workshops, parliamentary sessions, or District Assemblies) or other 'platforms' to facilitate discussions, protests or street actions; it is simply a matter of indifference, resulting from the fact that "they probably don't see how that is going to benefit them. What they know is that they are making their films and they are making their money. Bill or no Bill, they are making it". Respondents are also emphatic that effective campaign for policy changes will require, not only the collaboration of all associations within the industry, but also respect for regional trade and cultural policy agreements signed by ECOWAS member states. Where these treaties are disregarded, as it was the case with FIPAG-Nollywood controversy of 2010, it could have negative consequences in terms of cordial business relationship among sister nations in West Africa.

\section{c) Nigeria}

Respondents from Nigeria note that independent short filmmakers intervene in film policy reforms primarily through the television stations that lean on their services and/or through the independent marketers. Chukwumba, for instance, maintains that it is the elitist associations of marketers that constitute one of the key film policy stakeholders alongside government. Though short film producers in the country have no common business interest with the marketers, strategically, the small film producers do succumb to the political agendas of the marketers in order to find some form of representation in policy matters. Chukwumba submits that the low-budget film sector currently lacks a unified and well-structured association that could be brought forward for inclusion in film policy decisions. The power of direct intervention and participation is enjoyed only by the independent television sector and the private marketers alongside other stakeholders. Chukwumba is emphatic that, though short film producers in Nigeria are not completely marginalized in film policy processes, their level of direct participation is low. The sector still has a lot to do to gain separate representation outside those provided by the independent television industry and the elite marketers. The "Homevida" project, Chukwumba observes, is a big opportunity for them to use and build their alliances.

\section{Film Policy Changes: Achievements and Challenges}

That all the achievements and challenges of the alternative filmmaking sector in Nigeria, Ghana, and South Africa could be completely captured in these few pages is an overstatement. Only a few highlights are given. But regardless of the challenges confronting the sector, evidence suggests that the independent short filmmakers, drawing on a number of strategies and working in partnership with a host of other organizations and government ministries, are achieving some level of victories in their activism for film policy reforms.

\section{a) South Africa}

Outside the pressures for changes in some sections of the 1978 Copyright Act of South Africa, Shwinges of SASFED maintains that the industry organization has made significant inputs, on behalf of the independent audio-visual sector, to influence government to undertake a television broadcast review process through DC, the government agency that co-ordinates media operations in the country, as well as to update South African audio-visual broadcast facilities in the areas of fidelity to content rules and effective management of 
the Digital Television Terrestrial (DTT) migration process. For him, these are some of the areas that SASFED and SOS collaborate to campaign for changes. In a short Skype chat with Shwinges in July 2015, he admits that the South African copyright law situation is still the same. The only difference is that DTI has finally responded to stakeholders' appeal by setting up a hearing committee to make recommendations to the Minister on the review of the Copyright Act. And SASFED has made a representation to that committee.

SASFED has also participated in "The-Right-to-Know" campaign undertaken by all civil society organizations in protest against the proposal for a "Public Information Secrecy Act" put forward by the conservative arm of ANC-led government. The South African government is trying to make it punishable by law for journalists, broadcasters, and audiovisual producers to publish certain information without first clearing it with government. What this means is that any cultural producer and their sources could be put in prison on the basis of that law if the parliament approves it. Shwinges maintains that "the Secrecy Act" proposal is of a grave concern to the general public because of the way it will deny the media access to some information considered by the State as "classified" information. The proposal will be problematic not only for newspaper and broadcasting institutions, but also for low-budget filmmakers in their depiction of sociopolitical realities in South Africa. It will bear serious consequences for freedom of expression guaranteed in the 1996 Constitution of South Africa by creating spaces for government "to ban any film at any time that they see as detrimental to the interest of the ruling party". Evidently, legislation on that Bill has been delayed due to the enormous pressure against it from "The-Right-to-Know-Campaign" groups.

\section{b) Ghana}

GAFTA in Ghana has also made significant inputs into film policy reforms in Ghana. Awindor admits that the association made a significant input into the National Film Bill through the Ministry of Information. The primary reason for GAFTA's involvement was the unilateral way the official drafters of the Bill had approached it. GAFTA's involvement was also informed by its conviction that if the Bill was passed the way it was submitted, it would not favour the independent small film producers. Awindor maintains that with inputs coming from different industrial sectors, the Bill is now in a state that if approved will be acceptable to Ghanaians. He admits that GAFTA is quite optimistic about the Film Bill because it will provide a regulatory framework, not only in terms of "censorship", but in terms of structured guidelines for industrial operations and monitoring; as well as enable the industry provides opportunities for employment and the generation of additional revenue for government. Evidently, pressure for the formation and quick passage of the Film Bill remains one of the major issues that sometimes unite GAFTA and FIPAG in advocacy. The drive to actualize the Film Bill has, at different times, brought the two bodies together to lobby whoever is the Minister of Information in Accra.

\section{c) Nigeria}

The Homevida Award scheme remains one of the biggest achievements that have enabled broader participation of young talents in the cinema industry in Nigeria. In particular, the event has opened up spaces for those in the small film sector to find platforms for synergy and collaboration, in a way that will allow them have a distinctive voice in film policy decisions in the country. However, evidence suggests that the low-budget sector did contribute through the private marketers and private television houses towards the formulation of the policy document on the "Distribution, Exhibition and Marketing of Films and Video Works in Nigeria". The policy framework, Chukwumba explains, will be implemented and realized in three "phases" (the "distribution and exhibition licensing"; the introduction of "General Classification Labels" that is carried out with film certification process; and the "Scratch Card Classification Label" which is still on course). All three 'phases', he explains, constitute a single ongoing regulatory practice in the country. He indicates that the key direct contributors to this document were government experts, private television establishments, and the private marketer associations. Though the small film producers did not have any separate representation, they did make their impacts through these other groups.

In spite of these achievements, the small film industries across the three countries are still faced with numerous challenges. Primary among them are funding and infrastructural support, training to ensure high production quality, access to film regulators especially in South Africa, the enduring communication gaps between industry organizations and agencies of government, as well as harassments from those in government who do not agree with the views of those in the alternative cinema sector. SASFED, for instance, in lobbying for changes in the broader regulatory landscape in South Africa, is constantly being harassed by boras departments in government that put up mirage documents against them. But the political pressure, rather than discourage SASFED, emboldens it to form more alliances with civil societies to pressure government for attitudinal and policy changes.

\section{Conclusions}

This chapter set out to address three questions in relation to the relationship between short film and video producers and film policy developments in the English-speaking region of Africa: how can we reconceptualize film policy to ensure sophistication and acceptance among alternative film producers? What is the contributive role of short film producers in film policymaking? Is there identifiable democratic deficit in the sociopolitical dynamics of film policymaking in the African region? Focusing attention on 
the developments in Ghana, South Africa, and Nigeria, this work has argued for the adoption of the ethical-political policymaking framework, so as to ensure wider participation and the broadening of the sociopolitical dynamics for co-regulation of cinema industries in Africa. The rational for this argument rests on the need for academics, civil society organizations, and conveners of film policy debates to continue to work to ensure the inclusion of the empathetic and moral considerations of citizenship in official film policy agendas.

With regards to democratic deficit and the degree of participation of the small film sector in film policy developments of the last two decades, the general finding is that the independent short film producers of Anglophone Sub-Saharan Africa lack separate representation in the official film policymaking forums. As a result, they make little direct input into film policy reforms. Their interventionist contributions come mostly by way of partnerships with industry organizations, local television houses, and at film festivals. The problem with their minimal direct intervention is not lack of 'forums' and other 'platforms' to facilitate discussions, protests or street actions; it is simply a matter of indifference, resulting from the fact that they probably don't see how that is going to benefit them commercially. However, while the independent short film sector is not completely excluded from the sociopolitical dynamics of film policy making in Africa, ongoing campaigns for broader collaboration among all relevant associations within the industry is necessary. Also relevant is the need for all stakeholders to work together to continue to create meaningful interfaces between commercialism and cultural considerations in national film policy debates, as well as ensure ongoing respect for regional trade and cultural policy agreements in policy decisions in Africa.

However, in view of the challenges still confronting the national cinema industries as a whole and the growth of short film practice in particular, this chapter makes the following recommendations in prospect of future activism for film policy reforms in Africa: the adoption of the 'ethical-political' policy conception framework and 'open' administrative approach by industry regulators to broaden participation; the need for the formation of separate representation by short filmmakers outside those provided by the independent television industry and the elite marketers, to enable them partner more meaningfully with diverse industry organizations and with governments; increasing use of social media platforms by low-budget film producers to strengthen presence and direct engagement with activist organizations and governments; as well as the need for diversification in funding and expansion in the protective frameworks available to small film producers across Africa.

\section{REFERENCES}

[1] Bordwell, D. and Thompson, K. Film as art: creativity, technology, business, In David Bordwell and Kristin Thompson. Film art: an introduction. $8^{\text {th }}$ ed. (Boston \& London: McGraw-Hill, 2008)

[2] Botha, M. South African Cinema 1896-2010 (Bristol, UK \& Chicago, USA: Intellect, 2012)

[3] Calhoun, C. Introduction: Habermas and the Public Sphere. In Craig Calhoun. editor. Habermas and the Public Sphere (Cambridge, Massachusetts and London, England: The MIT Press, 1992: 1-48)

[4] Chakravartty, P. and Sarikakis, K. Media Policy and Globalization (Edinburgh: Edinburgh University Press, 2006)

[5] Croft, S. Concepts of national cinema. In John Hill and Pamela Church Gibson. editors. The Oxford Guide to Film Studies (Oxford \& New York: Oxford University Press, 1998: 385-94)

[6] Downing, J. Radical Media: The Political Experience of Alternative Communication (Boston: South End Press, 1984)

[7] Eaton, M. editor. Anthropology - Reality - Cinema: The Films of Jean Rouch (London: British Film Institute, 1979)

[8] Enzensberger, H. M. Constituents of a Theory of the Media. In Denis McQuail. editor. Sociology of Mass Communications (Harmondsworth: Penguin, 1970: 99-116)

[9] Erickson, M. P. A. Independent Filmmaking in the Pacific Northwest: A Critical Analysis of the Regional Film Landscape. A Dissertation (Eugene: The University of Oregon Graduate School, 2011.June)

[10] Guneratree, A. R. and Dissanayake, W. Alternative cinemas in the age of globalization. In Guneratree and Dissanayake. editors. Rethinking Third Cinema (New York \& London: Routledge, 2003: 101-02)

[11] Habermas, J. The Structural Transformation of the Public Sphere. Thomas Burger. 1989 trans. (Cambridge, UK \& Oxford, UK: Polity, 1962)

[12] Hallin, D. and Mancini, P. Western media systems in comparative perspective. In James Curran. editor. Media and Society. $5^{\text {th }}$ ed (London \& New York: Bloomsbury, 2010: 103-21)

[13] Humphreys, P. J. Media and Media Policy in Germany: The Press and Broadcasting Since 1945. German Studies Series. 2nd ed (Oxford \& Providence-USA: Berg, (1994)

[14] Hutchison, D. Media Policy: An Introduction (Oxford, UK \& Malden, USA: Blackwell, 1999)

[15] Le Grice, M. Experimental Cinema in the Digital Age. BFI Film Classics (London: British Film Institute, 2001)

[16] MacDonald, S. A Critical Cinema: Interviews with Independent Filmmakers (Berkeley: University of California Press, 1988)

[17] Marris, P. and Thornharm, S. Media Studies: A Reader. $2^{\text {nd }}$ ed (London: NYU Press, 2000)

[18] Moran, A. Terms for a Reader: Film, Hollywood, national cinema, cultural identity and film policy. In Albert Moran. editor. Film Policy: International, National and Regional Perspectives (London \& New York: Routledge, 1996: 1-20)

[19] National film and video foundation. Draft Report on the 
National Film and Video Foundation Third Film Indaba (Houghton-South Africa, 2010 March)

[20] Negt, O. and Kluge, A. Public Sphere and Experience: Toward an Analysis of the Bourgeois and Proletarian Public Sphere, P. Labanyi, J. Daniel \& A. Oksiloff. trans. (Minneapolis: University of Minnesota Press, 1993)

[21] Okon, P. E. Changes in Media Policy in Sub-Saharan Africa: The Role of Community Media. A Doctor of Philosophy Thesis (Edinburgh: Edinburgh Napier University, 2014)

[22] Papthanassopoulos, S. and Negrine, R. Approaches to Communications Policy: An Introduction. In Stylianos Papthanassopoulos and Ralph Negrine. editors. Communications Policy: Theories and Issues (England \& New York: Palgrave Macmillan, 2010: 3-21)

[23] Rabinovitz, L. Points of resistance: Women, power and politics in the New York avant-garde cinema, 1943-71. $2^{\text {nd }}$ ed
(Urbana, IL: University of Illinois Press, 2003)

[24] Rosenthal, A. The Documentary Conscience: A Casebook in Film Making (Berkeley: University of California Press, 1980)

[25] Sholle, D. Access Through Activism: Extending the Ideas of Negt and Kluge to American Alternative Media Practices, In Science Communication: An International and Interdisciplinary Journal of Social Philosophy. (Thousand Oaks: SAGE, 1995 2(4), 21-35)

[26] Sitney, P.A. Visionary Film: The American Avant-Garde, 1943-1978. $2^{\text {nd }}$ ed (New York: Oxford University Press, 1979)

[27] Smith, M. Modernism and the avant-gardes. In John Hill and Pamela Church Gibson. editors. The Oxford Guide to Film Studies (Oxford \& New York: Oxford University Press, 1998: 3395-412) 